\title{
The Egyptian Period in the History of Embalming
}

\author{
Milyukov Vladimir Yefimovich", *, Chilingaridi Svetlana Ninelievna ${ }^{2}$, \\ Sharifova Kheyalya Murshud Kizi ${ }^{1}$, Sharifov Elshan Rovshan Oglu ${ }^{3}$ \\ ${ }^{1}$ Department of Human Anatomy, Federal State Autonomous Educational Institution of Higher Education First Moscow State Medical \\ University I. M. Sechenov of the Ministry of Health of the Russian Federation (Sechenov University), Moscow, Russian \\ ${ }^{2}$ Department of Human Anatomy, Pirogov Russian National Research Medical University (RNRMU), Moscow, Russia \\ ${ }^{3}$ Head of the Clinic "Todays' Dental", Moscow, Russia
}

\section{Email address:}

milyucov@mail.ru (M. V. Yefimovich)

${ }^{*}$ Corresponding author

\section{To cite this article:}

Milyukov Vladimir Yefimovich, Chilingaridi Svetlana Ninelievna, Sharifova Kheyalya Murshud Kizi, Sharifov Elshan Rovshan Oglu. The Egyptian Period in the History of Embalming. International Journal of Clinical and Developmental Anatomy.

Vol. 6, No. 1, 2020, pp. 11-15. doi: 10.11648/j.ijcda.20200601.14

Received: November 25, 2019; Accepted: January 15, 2020; Published: February 10, 2020

\begin{abstract}
Since ancient times, people have sought to preserve the body of a deceased person as a container for his soul. Embalming originated in Egypt, presumably in 200 BC. and permission was used until 650 AD The need for embalming the bodies of the dead in Egypt was associated with religious beliefs that for this it was necessary to remain intact. The history of embalming is an interesting section of the science of man and has almost four millennia. It is known that the Egyptians skillfully embalmed the bodies of the dead, and no nation in the world could compete with them in this area. The embalming methods used by the Egyptians were changed in accordance with the usual and receiving embalmers. Modern research quite accurately restored the embalming process in Ancient Egypt, which was divided into several stages. The problem of preserving the bodies of the dead continues to worry scientists today, paving the way for modern anatomical technologies and contributing to their development. Based on the texts of the ancient Egyptian embalms, their unique, sometimes mysterious art, the teachings on embalming developed, improved and survived to this day. Centuries have passed in the time of Embalming, but the problem of preserving the bodies of the dead continues to worry scientists.
\end{abstract}

Keywords: Embalming History, Embalming Techniques and Methods, Embalming Categories in Egypt

\section{Introduction}

Since ancient times, man has sought to stop time and perpetuate the memory of loved ones. This desire and religious-mystical perception of a person's birth, his life and death were realized in an effort to preserve the body of a deceased person as a container of his soul. The history of embalming is an interesting section of the science of man and has almost four millennia. The peoples of South America embalmed the bodies of their deceased noble tribesmen. Embalming the bodies of deceased rulers was also widespread among the Persians, Assyrians, and ancient Egyptians [1,2].

\section{Historical Base of Development of Embalming}

The first information about the mysterious mummies stored in the Egyptian pyramids and the methods of embalming them became known from the works of the Egyptian expedition or the Egyptian campaign - a campaign undertaken in 1798-1801 on the initiative and under the direct supervision of Napoleon Bonaparte, whose main goal was an attempt to conquer Egypt, and the first of the Europeans who tried to solve the mystery of the Egyptian mummies were the French scientists Champollion and Rupee - participants of the Napoleonic expedition. The multivolume 
works of this expedition contain the first information about the mysterious mummies found in the Egyptian pyramids, and about the methods of embalming them.

Embalming originated in Egypt, presumably in $200 \mathrm{BC}$. and was used up to $650 \mathrm{AD}$ The need for embalming the bodies of the dead in Egypt was associated with religious beliefs that in order to revive a person in the next life, his body in this life should remain intact [3-6]. For the ancient Egyptians, life after death played an even greater role than direct life, therefore the preservation of the human body and the presence with it of various magical amulets and "essentials" were the main condition for a comfortable existence in the afterlife. Earthly life was only a period when people must do everything necessary so that their souls not only safely reach the world of the dead, but also take their rightful place there, having the opportunity to find eternal bliss. The whole complex funeral rite of Ancient Egypt, starting from mummification and ending with the construction of the pyramids, pursued precisely this goal. The basis of the funeral rite was the desire to preserve the body of a deceased person as long as possible, so that his soul would not wander around the world. "An Egyptian would have been executed by death if he had committed a small insult to the dead" (from the notes of the historian and ethnographer Count Kaylo).

It is not difficult to understand where the Egyptians got their first embalming techniques from. Egypt is a country of hot climate. Hunting and fishing made it possible to feed. The hunter or fisherman, having obtained more than he and his family could eat at a time, had to save an excess of fish, birds, and other game. He gutted her carcasses, removed the blood, and then, in one way or another, for example, salting, drying in the sun, smoking, or some other way, kept it for consumption in the future. It is not necessary to have a rich imagination to guess how easily the basic process of preserving food was adapted to preserve the dead with corresponding changes and was very simple.

Initially, during the early pre-dynastic period of Egyptian history, to preserve the bodies of the dead, an unbalanced body of the deceased was given an embryo pose (arms bent at the chest, legs bent at the knees and tucked up to the chin), wrapped in cloth or straw mats and laid in a shallow grave dug in the desert sands east of the Nile. In contact with dry porous sand, the bodies dried out and, thanks to the complete absence of rain and damp, persisted for a long time. The burials of the noble and wealthy Egyptians differed from the tombs of commoners only in the value of the objects placed in the grave and in that the pit was lined with planks or stone slabs from the inside [6-9].

With the development of civilization, cities and villages grew in Egypt; trade, state, military and religious services created sharply distinguished middle and upper classes of landowners and other noble residents, as well as the upper class of tribal leaders. Gradually, the natural mummification ceased to satisfy the Egyptians and methods of artificial embalming appeared in ancient Egypt, which became more sophisticated.
When one of the members of this group of aristocracy was dying, the traditionally simple burial in the sands of the desert was no longer enough. The graves began to dig deeper, lined with stone tiles. In the graves of these wealthy and noble deceased began to put valuable household items and jewelry.

One attempt to prevent decomposition was to place the body in a coffin made of a single piece of stone with a tight lid. In such burials, subsequently, the servants of the cemeteries and relatives ran into the remains, which completely turned into skeletons. Not knowing the scientific explanation of the decomposition of organic compounds and decay, they were sure that stone coffins "eat" soft tissues. Until today, massive bronze and copper coffins are called "sarcophagi" $[10,11]$. The word sarcophagus is part of the

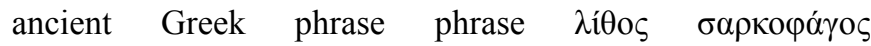
(lithossarcophagos, literally "stone eating flesh") and consists of Greek roots бá $\rho \xi$ (sarx "flesh, meat") and $\varphi \alpha \gamma \varepsilon \tilde{v}$ (phagein "eat"). The Egyptians, not wanting to return to a simple burial in the sand, found it necessary to develop a system for protecting the human body - embalming [11].

The first embalm, according to ancient Egyptian legend, was Anubis, one of the most respected gods of Ancient Egypt, the son of the god of vegetation Osiris, who later became the god of the underworld and the sovereign of the souls of the dead. When Seth killed Osiris, Anubis helped preserve the body of Osiris by organizing the burial of the deceased god, wrapped his body in fabrics saturated with a special composition, thus making the first mummy. Therefore, it is Anubis who is considered the creator of funeral rites, the patron saint of necropolises, and is called the god of embalming. His name is mentioned in all the funeral Egyptian literature, according to which one of the most important functions of Anubis was to prepare the body of the deceased for embalming and turning it into a mummy. Anubis also helped judge the dead and accompanied the righteous to the throne of Osiris. Anubis is the Greek version of his name, the ancient Egyptians knew him as Anpu (or Inpu). The ancient Egyptians believed that preserving the body and using fragrant herbs and plants would help the deceased, because Anubis would smell the mummy and only clean would allow him to go to heaven. According to legend, he taught the art of embalming the ancient Egyptians. [8, 9, 12].

History has preserved the testimonies of four authors of that time, which are often quoted, talking about embalming methods in ancient Egypt. The earliest description of embalming methods belongs to the Greek historian Herodotus of Halicarnassus, who lived around 484 BC. The second author - Diodorus Siculus (Diodorus Sicilian), lived about 90 - 30 years. $\mathrm{BC}$ e. The third description is given by Plutarch - the full name is Metrius Plutarch (dr. Greek $\Pi \lambda$ ov́ $\alpha \rho \chi 0 \varsigma)$, who lived between 50 and 100 years. The

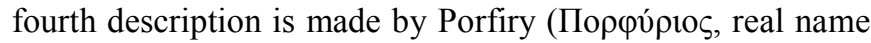
Malch, or Melech), who lived around 230-300. [8] Modern Egyptologists consider reports of embalming Porfiry and Plutarch unreliable, but recognize the reliability of the reports 
of Herodotus and Diodorus.

The embalming methods used by the Egyptians varied in accordance with the customs and methods of a particular embalming. Modern research accurately restored the embalming process in Ancient Egypt, which was divided into several stages. There was a whole group of people who devoted themselves to embalming and engaged in this art; these people, when they brought the deceased to them, showed customers wooden models of finished mummies. The embalming process was very long and complicated, it was carried out in four categories and, accordingly, embalming categories were charged. Initially, relatives agreed on a price, then, together with friends, acquaintances, and weepers, they brought the corpse into the courtyard of the temple. Embalming was accompanied by a ritual established by the priests and ceremonies.

In the first category, the corpses of noble people were embalmed. First, the brain was removed from the body through the nasal openings with a special hook, for which the ethmoid bone was hollowed out and the membrane of the brain was removed with special forceps. Sometimes they did this with a special hook or spoon through the nostrils or reached the brain through the orbits. There is a record of a case when the brain was removed from the skull through the large occipital foramen after removal of the first cervical vertebra.

Embalming was performed with opening the cavities. At first, the draftsman marked with paint the place of the cut on the stomach of the corpse, then with a bronze knife or Ethiopian stone he made a cut of the abdomen and removed all the insides, after which the body cavities were washed with palm wine. The interiors of the corpse were packed in a box, sprinkled with aromatic powder, after which the priests transported them to the other side of the Nile and, singing a special prayer to the god of the Sun, were dumped into the water $[4,8]$. The interiors of the pharaohs and especially noble dead were placed in special canopical vessels, the covers of which were crowned with the heads of the four children of the god Horus with the image of a man "canopies" and stored with the dead man. In a vessel crowned with a human head representing the god Imset, the liver was stored. The vessel, covered with a lid with the head of a jackal, depicting the god Duamutef, contained a stomach. A jug with a monkey head representing the god Hapi contained lungs. Intestine was stored in the fourth vessel, with the head of the Kabek-Snevef hawk. Nowhere is it mentioned where the spleen, pancreas and pelvic organs were placed $[5,8,12]$. The canopies were of different sizes and were made from various materials - alabaster, limestone, basalt, clay. When the insides were placed in these jugs, miniature canopies were embedded in body cavities, which were then stuffed with straw, bandage soaked with resin or moss and lichen. The canopies were placed in a wooden box and stored next to the body.

Sometimes when embalming a corpse, the heart was left in the chest, since it should come "to the next world" to the supreme judge and testify about the deceased, and only tell the truth. It is described that a stone was found in one of the mummies instead of a heart - it turns out that the deceased, even during his lifetime, ordered to make such a replacement, fearing revealing speech of the heart $[1,5,6,9,10]$.

The opened cavities of the body of the deceased were washed several times with palm wine and leaven, then poured with hot asphalt from the shores of the Dead Sea or pisiphalt (from the bottom of the sea). Sisyphalt - in Arabic the mummy and the first mention of it is found among the Greeks in the XII century. According to other sources, this is wax. Then the cavities were sutured, and the corpse was immersed in natron according to Herodotus for 70 days, according to Diodorus for 30 days. Natron consisted of a complex saline solution, which included potassium nitrate, sodium chloride and sulphide, potassium carbonate and lime. After the above period, the corpse was dried, rubbed with aromatic powder. Sometimes, after drying, the corpse was additionally immersed in a large jug with a solution of honey for 20 days. A small fire was maintained under the jug. After these procedures, a shirt was put on the corpse, which was laced up behind. Then the corpse was bandaged 15-20 times with silk bandages soaked in resins. It is the presence of several layers of thin bandages on the embalmed body that serves as another likely basis for the appearance of the word "mummy", since it can come from the Persian word mum "scroll".

The cuts on the body at first did not sew, but simply pulled their edges to each other. Sometimes the edges of the sections were glued with wax or resin, however, there are records from the 18th, 20th and 21st dynasties (1700, 1250 and 1000 $\mathrm{BC})$ about cases when the sections were stitched. Wired or not, the incision was covered with a plate of wax or metal.

The face of the deceased was covered with a piece of silk and painted. The art of portrait painting, which is characterized by a pronounced resemblance to a specific person, goes back to the Fayum portraits of Ancient Egypt. These memorial portraits were painted with wax on a whiteboard (in the early period of the first century BC, on canvas), which was then inserted into the mummy's bandages in place of the face. Due to the low chemical activity of wax, its moisture resistance, these posthumous portraits for many centuries preserved the freshness of color, density and texture of the paint layer. For the first time, archaeologists found them in the Egyptian oasis of Fayoum more than a hundred years ago - in 1887. A very rich deceased put a golden or silver mask on their faces. Sometimes the bodies of noble Egyptians were golden. Moreover, gold could cover both the entire mummy and only certain parts of the body (face, nails of fingers and toes, genitals).

Then proceeded to swaddle the mummy. It is believed that embalmers specialized in bandaging certain parts of the body - fingers, feet, head, etc. Each toe or hand was first bandaged separately, then each limb as a whole. The body was first covered with a kind of tunic, and the face with a square piece of bandage, followed by smooth spiral turns. Between the bandages there was a padding to maintain the contours of the body.

Mummies after swaddling were usually packed in boxes. Additional packaging, called "cartoning" by archaeologists, 
was made from 20-30 linen or papyrus sheets soaked in tar, gypsum or acacia juice. These sheets were wet overlaid on a swaddled body. To make the material tightly fit the mummy, it was pulled together on the back with a cord. Drying, the cardboard became strong as a tree. It was covered with a thin layer of plaster and painted with paints. A cardboard case was placed in two or more wooden boxes made of cedar or sycamore, one in the other. Coffins in the shape of the human body are called anthropoids. If the deceased came from a noble family, his mummy was enclosed in a stone sarcophagus made of marble, limestone, slate or granite.

Often sarcophagi were embedded one into another, sometimes there were up to 8 pieces, some of which were made of pure gold and decorated with precious stones. In 1922, British archaeologists discovered a secret and modest in size and appearance Tutankhamun's tomb, the interior of which, with a large number of works of art and jewelry, was in the same form in which it was walled up in the XIV century BC. In the tomb of Tutankhamun a funeral chamber was arranged, in which there was a large wooden box occupying the main part of the room, upholstered in sheet gold and covered with ritual hieroglyphs and images. Inside this box there was directly a stone sarcophagus of Tutankhamun, and already in the sarcophagus there were three coffins according to the principle of a nested doll, one in the other. The two outer coffins were wooden with gold elements and inlaid precious stones. And the third, the most modest in size coffin, was made of pure gold, the total weight of which was about 100 kilograms and directly contained the mummy of Tutankhamun, an analysis of which scientists provided science with a large amount of interesting information [9]. Thus, the sarcophagus of Tutankhamun is, as in the cases of all other burials of the pharaohs, ancient Egyptian nobles, as well as noble people of other civilizations of antiquity, from the Middle East to Italy, a stone tomb repeating the outline of the tomb placed inside it with common contours.

Embalming in the second category was performed without opening the cavities. Cedar or radish oil and a solution of caustic soda were poured into the corpse through the anus with a wooden syringe, which destroyed all the insides. After that, the corpse was immersed for 70 days in natron, dried, put on a shirt, bandaged and varnished.

When embalming in the third category, the corpse was only immersed in soda, dried and bandaged. Embalming in the fourth category was accessible even to the poor: the corpse was simply immersed in a solution of hot asphalt for several days, after which it was bandaged with canvas. Such mummies were black.

The corpses of children were not embalmed, since the Egyptians considered the children sinless [7, 9, 10].

It should be noted that the dry soil and hot climate of Egypt contributed to the mummification of corpses and their preservation for millennia. Mummies brought to Europe, under the influence of a damp and humid climate, quickly decayed into gray powder. Some authors believe that the Egyptian embalming method is not ideal, since the corpse was enclosed in an impenetrable case.

According to Elliot Smith in his article, knowledge of Egyptian embalming methods was transferred to the west, down to the Canadian islands [8, 13].

American mummies, discovered in caves in 1838, are similar to Egyptian mummies. The corpses were in a sitting position, many of them were sewn into the skin. The same corpses were found on Tierra del Fuego.

According to S. N. Delitsin, a Russian surgeon and anatomist who worked at the Warsaw Military Hospital in 1884-1887, he saw a corpse in Vilna, which stood like a bronze statue, without drying out for 70 years. The corpse is known as the priest, but they say that it belonged to a local executioner. The secret of embalming is unknown.

In the Talmud there are indications that in ancient times the corpses of people were preserved in honey. For example, King Herod kept the corpse of his wife Mariama in honey for 7 years. The corpse of the king of Macedonia, Alexander the Great, was also preserved for a long time in honey.

In ancient Jews, corpses were not embalmed according to their religious views. They wrapped the corpses in a canvas and quickly interred. But if a person was dying outside the house, his body was embalmed for delivery to his homeland $[7,14]$. Thus, in the book of Genesis (chap. 50) it is mentioned that Joseph ordered his ministers and doctors to embalm the body of his father Jacob to send him home. When Joseph himself died, he was embalmed in Egypt. In Genesis, the method of embalming is not specified, but it is noted that this took 40 days.

Arabs embalmed the corpses of only very noble deceased and only in exceptional cases. The embalming method and technique was primitive (cited by French sources - Razes) [9]. The corpse was placed head down and a solution of salt and "black covert" (unknown composition) were poured into a wooden syringe through it in a substantial amount. Then the corpse was laid in a horizontal position and pressure on the stomach freed him from this mixture. This has been done several times. After washing the intestines, the following mixture was poured into it in the above manner: rose water, camphor, aloe and the anus was closed with a stopper. Then the corpse was carefully rubbed with salt and mercury and abundantly watered with incense oils and sprinkled with aromatic powder. After that, the corpse was wrapped in silk or canvas.

\section{Conclusion}

Based on the texts of the ancient Egyptian embalms, their unique, sometimes mysterious art, the doctrine of embalming developed, improved and survived to this day.

The famous Russian biologist D. Vyvodtsev, who lived in the last century, notes that the Egyptians artistically embalmed the bodies of the dead and not a single nation of the world could compete with them in this area. At the same time, the Russian scientist indicates that, despite numerous studies, all the substances that were used by the Egyptians to preserve the bodies of the dead are not known. In their desire to confront the destructive forces of nature, they turned to 
natural means, seeking out new opportunities, improving for many centuries the art of preserving incorrupt their dear dead, unconsciously paving the way for modern anatomical technology and promoting its development. Centuries have passed since the beginning of embalming, but the problem of preserving the bodies of the dead continues to worry scientists.

\section{References}

[1] Sapin M. R. "Human Anatomy" ed. Medicine, 1996, S. 9-12.

[2] Nicolenko E. S. The mystery of the embalming from egiptian mummies to present days. Bulletin of the Council of Young Scientists and Specialists of the Chelyabinsk Region. 2016; 2 (2-15): 46-49.

[3] Venediktov A. S. «Sposob bal'zamirovanija trupov i prevrashhenie ih v mumii». Uchenye zapiski; Har'kov - 1899 g. S. $10-25$.

[4] Koncevich I. A., Lysenko O. B., Mihajlichenko B. V., Mel'nichenko V. P. «Datirovanie srokov zahoronenija trupov mnogovekovoj davnosti» Pervyj s\#ezd sudebnyh medikov Kazahstana. Chemkent - 1989 g. S. 30-32.

[5] Brenner E. Human body preservation - old and new techniques. J Anat. 2014; 224 (3): 316-344. doi: 10.1111/joa.12160.

[6] Jones J, Higham T. F. G., Oldfield R., O'Connor T. P., Buckley S. A. Evidence for Prehistoric Origins of Egyptian Mummification in Late Neolithic Burials. PLoS One. 2014; 9 (8): e103608. doi: 10.1371/journal.pone.0103608.

[7] Gusovskaja N. D. «K voprosu issledovanija vysohshih tkanej» Trudy sudebno-medicinskih jekspertov Ukrainy. Kiev - 1958 g. S. $301-308$

[8] Kuznecov L. E., Hohlov V. V., Fadeev S. P., Shigeev V. B. «Bal'zamirovanie i restavracija trupov» Rukovodstvo. Smolensk- Moskva, izd. Profizdat, 1999 g., S. 21-30.

[9] Jaroslavcev B. M. «Istorija bal'zamirovanija trupov i tvorcy russkoj anatomicheskoj tehniki» Tipografija upravlenija poligrafiz data, g. Frunze, 1960 g., S. 7-21.

[10] Clark K. A., Ikram S., Evershed R. P. The significance of petroleum bitumen in ancient Egyptian mummies. Philos Trans A Math Phys Eng Sci. 2016; 374 (2079): 20160229. doi: 10.1098/rsta.2016.0229.

[11] Minakov P. A. «O konservirovanii i mumifikacii trupov» Russkij antropologicheskij zhurnal. M., 1924 g., t. 23, vypusk №1, S. 27-37.
[12] Kolesnikov A. M., Jetingen L. E. «Za predelami uchebnika anatomii cheloveka» M., 2013 g., OOO Izdatel'skopoligraficheskij kompleks Vest', S. 12-13.

[13] Violin D. A. «Bal'zamirovanie, mumii i moshhi» Smolensk 1936 g., S. 16-44.

[14] Kostylev V. I., Popov I. V. «Daktiloskopirovanie mumificirovannyh trupov» Sudebno-medicinskaja jekspertiza. M.: Medicina - 1974 g., №1, 50s.

[15] Moissidou D, D Day J, Shin DH, Bianucci R. Invasive versus Non Invasive Methods Applied to Mummy Research: Will This Controversy Ever Be Solved? Biomed Res Int. 2015; 2015: 192829. doi: 10.1155/2015/192829.

\section{Biography}

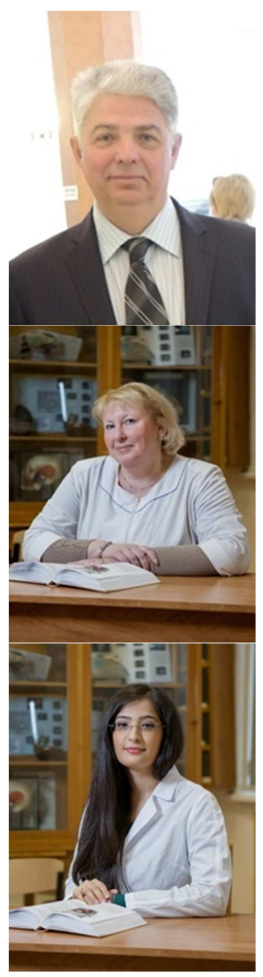

Milyukov Vladimir Yefimovich, Doct. of Med. Sci., Professor, Chair of Human Anatomy, Federal State Autonomous Educational Institution of Higher Education I. M. Sechenov First Moscow State Medical University of the Ministry of Health of the Russian Federation (Sechenov University).

Chilingaridi Svetlana Ninelievna, $\mathrm{PhD}$, Candidate of Medical Sciences, Senior Lecturer, Pirogov Russian National Research Medical University (RNRMU), Moscow, Russia.

Sharifova Kheyalya Murshud Kizi, Cand. of Med. Sci., Graduate Student and Assistant, Chair of Human Anatomy, Federal State Autonomous Educational Institution of Higher Education I. M. Sechenov First Moscow State Medical University of the Ministry of Health of the Russian Federation (Sechenov University).

Sharifov Elshan Rovshan Oglu, head of the clinic, Today's Dental. Moscow, st. Novomarinsky, 30. 